\title{
Crop and Soil Nitrogen Dynamics in Annual Strawberry Production in California
}

\author{
Thomas G. Bottoms and Timothy K. Hartz ${ }^{1}$ \\ Department of Plant Sciences, University of California, 1 Shields Avenue, \\ Davis, CA 95616

\section{Michael D. Cahn and Barry F. Farrara \\ University of California Cooperative Extension, 1432 Abbott Street, Salinas, CA 93901}

Additional index words. fertilizer efficiency, controlled-release fertilizer, water quality, Fragaria $\times$ ananassa Duch

\begin{abstract}
The impact of strawberry production on nitrate contamination of groundwater is of major concern in the central coast region of California. Nitrogen $(N)$ fertilization and irrigation management practices were monitored in a total of 26 fall-planted annual strawberry (Fragaria $\times$ ananassa Duch.) fields in 2010 and 2011. Soil mineral N (SMN, top $30 \mathrm{~cm}$ depth) was determined monthly. Irrigation applied was monitored, and crop evapotranspiration $\left(\mathbf{E T}_{\mathrm{c}}\right)$ was estimated. Growers were surveyed regarding their $\mathbf{N}$ fertilization practices. Aboveground biomass $\mathrm{N}$ accumulation was estimated by monthly plant sampling in seven fields. The effect of preplant controlled-release fertilizer (CRF) rate on fruit yield was investigated in three fields. The growers' CRF application rate (121 or 86 $\mathrm{kg} \cdot \mathrm{ha}^{-1} \mathrm{~N}$ as $18 \mathrm{~N}-3.5 \mathrm{P}-10.8 \mathrm{~K}$, 7- to 9-month release rating) was compared with a half rate (all fields) and no CRF in one field. The rate of $\mathrm{N}$ release from this CRF product was evaluated using a buried bag technique. Median CRF $N$ and total seasonal $N$ application (CRF + in-season fertigation through drip irrigation) were 101 and $260 \mathrm{~kg} \cdot \mathrm{ha}^{-1}$, respectively, with total seasonal $N$ application varying among fields from 141 to $485 \mathrm{~kg} \cdot \mathrm{ha}^{-1}$. Biomass N accumulation was slow through March (less than $25 \mathrm{~kg} \cdot \mathrm{ha}^{-1}$ ) and then increased by $\approx 1.1 \mathrm{~kg} \cdot \mathrm{ha}^{-1} \cdot \mathrm{d}^{-1}$ from April through mid-September. Mean seasonal biomass $\mathrm{N}$ accumulation was estimated at $225 \mathrm{~kg} \cdot \mathrm{ha}^{-1}$ by $15 \mathrm{Sept}$. Approximately $70 \%$ of CRF N was released before 1 Apr. Biomass $N$ accumulation between planting and April was much lower than the combined amount of CRF $N$ release and SMN decline over that period, suggesting substantial winter $\mathbf{N}$ loss. Conversely, $\mathbf{N}$ loss during the summer harvest season (May through August) appeared limited in most fields. Median SMN was maintained below $10 \mathrm{mg} \cdot \mathrm{kg}^{-1}$, and median irrigation was $113 \%$ of estimated $\mathrm{ET}_{\mathrm{c}}$ during this period. Reduction in CRF rate did not affect marketable fruit yield in two of three trials; an $8 \%$ yield reduction was observed in the remaining trial when the CRF rate was reduced, but the decline may have been affected by spring irrigation and fertigation practices.
\end{abstract}

California produces more than $80 \%$ of the U.S. strawberry crop (USDA, Economic Research Service, 2012) with production centered in the coastal valleys of central California. In this region an annual cropping system is used in which transplants are planted into fumigated, plastic mulched beds in the fall and usually grown for 9 to 12 months. Sprinkler irrigation is generally used to establish the transplants with drip irrigation used exclusively thereafter. $\mathrm{N}$ fertility is typically managed by a combination of preplant CRF application and in-season $\mathrm{N}$ fertigation. There has been a significant evolution over recent decades in cultural practices used and in cultivars grown; yields have increased $140 \%$ over the past 50 years (Shaw and Larson, 2008) and now commonly exceed $70 \mathrm{Mg} \cdot \mathrm{ha}^{-1}$.

Received for publication 1 Mar. 2013. Accepted for publication 11 June 2013.

${ }^{1}$ To whom reprint requests should be addressed; e-mailtkhartz@ucdavis.edu. to maximize fruit yield in annual production systems (Albregts et al., 1991a; Hochmuth et al., 1996; Kirschbaum et al., 2006; Locascio and Martin, 1985; Miner et al., 1997; Santos and Chandler, 2009). Splitting N application between preplant fertilization and in-season fertigation has been shown to be beneficial. Preplant application of no more than $67 \mathrm{~kg} \mathrm{~N} /$ ha (Albregts and Chandler, 1993; Miner et al., 1997) and in-season fertigation averaging between 0.5 and $0.9 \mathrm{~kg} \cdot \mathrm{ha}^{-1} \cdot \mathrm{d}^{-1}$ (Hochmuth et al., 1996; Miner et al., 1997; Santos and Chandler, 2009) were adequate to achieve peak fruit production. However, these studies reported on production systems with different environmental conditions, shorter production seasons, and lower yield and therefore may not be directly applicable to California conditions.

Irrigation is intrinsically linked to $\mathrm{N}$ management both as an $\mathrm{N}$ application method and as a primary influence on $\mathrm{NO}_{3}-\mathrm{N}$ leaching. Shallow rooting depth (Strand, 1994), and sensitivity to soil salinity (Maas, 1984) and low soil water potential (Serrano et al., 1992), make efficient strawberry irrigation management challenging. Hanson and Bendixen (2004) found that seasonal irrigation applied to seven California strawberry fields ranged from underirrigation to a leaching fraction of $28 \%$.

The primary objective of this study was to document plant and soil $\mathrm{N}$ dynamics in annual strawberry production under the environmental conditions and current grower management practices of the central coast region of California. Additionally, strawberry response to preplant CRF application rates was evaluated in three commercial field trials.

\section{Materials and Methods}

Plant and soil monitoring. Fertilization and irrigation practices were monitored in a total of 26 commercial strawberry fields in the Salinas and Pajaro Valleys in central California during the 2009-10 and 2010-11 production seasons. This area has a mild, marine climate with precipitation concentrated during the winter [Fig. 1; data from the California Irrigation Management Information System (CIMIS; Pruitt et al., 1987)]. All but one field (previously planted to strawberries) had produced cool-season vegetables in the spring before fall strawberry planting. After prior crop residue incorporation, fields were chemically fumigated in September to October. Fields were planted in October to November using transplants of 'Albion' (nine fields) or a proprietary cultivar (17 fields); both cultivars had a day-neutral fruiting habit. Field configuration was either two or four plant rows per raised, plasticmulched bed; bed height ranged from $\approx 20$ to $30 \mathrm{~cm}$. Bed width was 1.2 to $1.3 \mathrm{~m}$ for two row plantings and 1.5 to $1.6 \mathrm{~m}$ for four row plantings. Plant population varied from $\approx 50,000$ to 70,000 ha. Sprinkler irrigation was used for transplant establishment in most fields with drip irrigation used thereafter in all fields. Monitoring was done in 17 fields during the $2009-10$ production season and in 
nine different fields during the 2010-11 season. Fertilization records were obtained from the growers of 15 of the 26 monitored fields.

In this region, limited plant growth occurs through the winter months with fruit harvest typically beginning in April. Soil samples [top $30 \mathrm{~cm}$, the zone containing the majority of roots (Strand, 1994)] were collected at approximately monthly intervals from April to September. Additionally, soil samples were collected at transplant establishment in the 2010-11 fields. A minimum of 12 cores was collected and blended to make one composite sample on each sampling date with two $2 \mathrm{~N} \mathrm{KCl} \mathrm{extracts} \mathrm{prepared} \mathrm{from} \mathrm{each} \mathrm{composite}$ sample. Care was taken during soil sampling to avoid the bands of CRF applied below the plant rows. Soil mineral N (SMN, $\mathrm{NO}_{3}-\mathrm{N}$, and $\mathrm{NH}_{4}-\mathrm{N}$ ) was determined by the methods of Doane and Horwath (2003; for $\mathrm{NO}_{3}-\mathrm{N}$ ) and Forster (1995; for $\left.\mathrm{NH}_{4}-\mathrm{N}\right)$. Additional analyses were conducted on the first soil sample collected in each field. Soil texture was quantified by the hydrometer method of Sheldrick and Wang (1993). Phosphorus availability was estimated by a colorimetric method (Prokopy, 1995) following bicarbonate extraction (Olsen and Sommers, 1982). Exchangeable potassium (K) was measured by atomic emission spectrometry after ammonium acetate extraction (Thomas, 1982).

Plant sampling to document aboveground biomass $\mathrm{N}$ accumulation was conducted in four fields during the 2009-10 production season and three fields during the 2010-11 season. Sampling was initiated in late March to early April and repeated at approximately monthly intervals until late August to midSeptember. At the initial sampling, three areas in each field were identified as having plants of representative vigor. A composite sample from each area was collected by combining the aboveground biomass of four

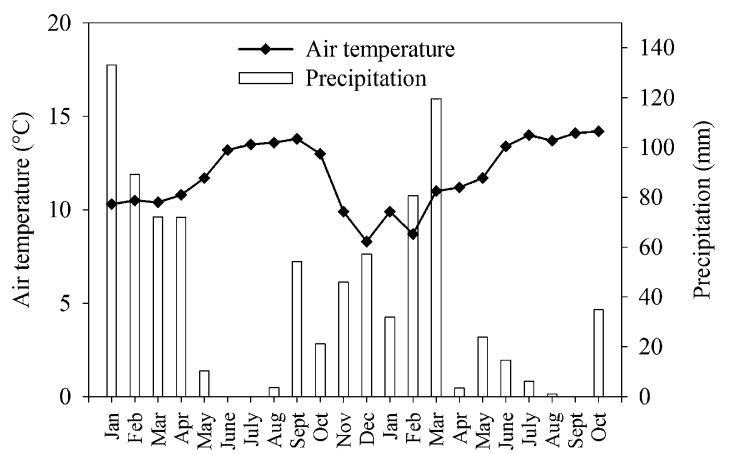

Fig. 1. Monthly precipitation and monthly mean air temperature in Castroville, CA, from Jan. 2010 through Oct. 2011.

Table 1. Production season, nitrogen $(\mathrm{N})$ fertilization, and marketable yield obtained in 26 strawberry fields.

\begin{tabular}{|c|c|c|c|c|c|c|}
\hline \multirow[b]{2}{*}{ Field } & \multirow[b]{2}{*}{ Production season } & \multirow[b]{2}{*}{ Soil texture } & \multicolumn{3}{|c|}{$\mathrm{N}$ applied $\left(\mathrm{kg} \cdot \mathrm{ha}^{-1}\right)^{\mathrm{z}}$} & \multirow{2}{*}{$\begin{array}{l}\text { Marketable yield } \\
\left(\mathrm{Mg} \cdot \mathrm{ha}^{-1}\right)\end{array}$} \\
\hline & & & Preplant & Fertigated & Total & \\
\hline 1 & \multirow[t]{17}{*}{$2009-10$} & Clay loam & & & & 71 \\
\hline 2 & & Clay loam & & & & 87 \\
\hline 3 & & Loamy sand & 101 & 159 & 260 & 80 \\
\hline 4 & & Clay loam & & & & 89 \\
\hline 5 & & Clay loam & & & & 89 \\
\hline 6 & & Clay loam & & & & 85 \\
\hline 7 & & Sandy loam & & & & 77 \\
\hline 8 & & Silt loam & & & & 75 \\
\hline 9 & & Silt loam & & & & \\
\hline 10 & & Silt loam & 50 & 259 & 309 & \\
\hline 11 & & Clay loam & & & & 87 \\
\hline 12 & & Loam & 60 & 172 & 233 & \\
\hline 13 & & Sandy loam & & & & 99 \\
\hline 14 & & Clay loam & 114 & 65 & 179 & 73 \\
\hline 15 & & Loam & 101 & 102 & 203 & 99 \\
\hline 16 & & Loam & 87 & 250 & 337 & 62 \\
\hline 17 & & Sandy loam & 101 & 40 & 141 & 73 \\
\hline 18 & \multirow[t]{10}{*}{$2010-11$} & Silty clay loam & 67 & 130 & 197 & 74 \\
\hline 19 & & Clay loam & 0 & 181 & 181 & 48 \\
\hline 20 & & Sandy clay loam & 134 & 351 & 485 & 56 \\
\hline 21 & & Sandy clay loam & 134 & 340 & 475 & 56 \\
\hline 22 & & Clay loam & & & & \\
\hline 23 & & Sandy loam & 121 & 218 & 339 & \\
\hline 24 & & Sandy clay loam & 121 & 175 & 296 & 78 \\
\hline 25 & & Loam & 121 & 249 & 370 & 77 \\
\hline 26 & & Clay loam & 86 & 96 & 183 & 99 \\
\hline Media & & & 101 & 175 & 260 & 77 \\
\hline
\end{tabular}

${ }^{\mathrm{z}}$ Missing values indicate the grower would not divulge $\mathrm{N}$ application data. plants. On subsequent sampling dates, plants were collected within a $30-\mathrm{m}$ radius of the initial samples. Fruit were removed and the remaining tissue was dried, weighed, and ground to pass a $0.4-\mathrm{mm}$ screen. Total $\mathrm{N}$ was determined using a combustion analyzer (Elemental Combustion System 4010; Costech Analytical Technologies Inc., Valencia, $\mathrm{CA}$ ). The $\mathrm{N}$ concentration of ripe fruit was also determined at each sampling date by the same technique, and the $\mathrm{N}$ content of fruit harvested between sampling dates was estimated by multiplying fruit $\mathrm{N}$ concentration on a fresh weight basis by the marketable yield during that period as reported by the cooperating growers.

Irrigation monitoring. Irrigation volume applied was recorded using pulse output flow meters (Netafim USA, Fresno, CA; McCrometer, Inc., Hemet, CA) connected to data loggers (CR200; Campbell Scientific, Logan, UT). In the 2009-10 production season, the meters were installed in March and recorded drip irrigation applied through September. In the 2010-11 season, water meters were installed in the fall and recorded irrigation applied for transplant establishment (sprinkler and/or drip) as well as all drip irrigation applied through the next September. Daily reference evapotranspiration $\left(\mathrm{ET}_{\mathrm{o}}\right.$, modified Penman) was obtained from CIMIS using the "spatial CIMIS" feature (Hart et al., 2009). This feature estimated $\mathrm{ET}_{\mathrm{o}}$ at specific GPS locations through interpolation of data from nearby weather stations. The extent of plant canopy development was estimated using digital infrared photography (camera model ADC and PixelWrench 2 software; Tetracam Inc., Chatsworth, CA) in 25 of 26 fields. Images were acquired on 4 to 5-week intervals beginning in March and extending into September. Canopy cover data for each field were fit using a polynomial model to calculate a percent canopy cover estimate for each day from 1 May through 30 Sept., the period during which most irrigation was applied. Daily crop coefficients $\left(\mathrm{K}_{\mathrm{c}}\right)$ were then calculated by the equation of Grattan et al. (1998):

$$
\mathrm{K}_{\mathrm{c}}=-0.000125 \mathrm{G}^{2}+0.02 \mathrm{G}-0.10
$$

where $G$ represented the percent of ground covered. Daily $\mathrm{ET}_{\mathrm{c}}$ was estimated by multiplying the corresponding $\mathrm{K}_{\mathrm{c}}$ and $\mathrm{ET}_{\mathrm{o}}$ values. Cumulative $\mathrm{ET}_{\mathrm{o}}$ and $\mathrm{ET}_{\mathrm{c}}$ from 1 May through 30 Sept. were compared to evaluate seasonal irrigation management.

Controlled-release fertilizer performance. The effect of pre-plant CRF application rate on strawberry growth, $\mathrm{N}$ uptake, and fruit yield was evaluated in three fields during the 2010-11 production season (fields 24,25 and 26; Table 1). Fields 24 and 25 were planted with 'Albion', whereas field 26 was planted with the proprietary cultivar. The cooperating growers applied the same CRF material in all fields $(18 \mathrm{~N}-3.5 \mathrm{P}-10.8 \mathrm{~K}$, rated as 7 - to 9-month release) in bands 10 to $15 \mathrm{~cm}$ deep below the plant rows; CRF application was made in October before application of plastic bed mulch in preparation for transplanting in 


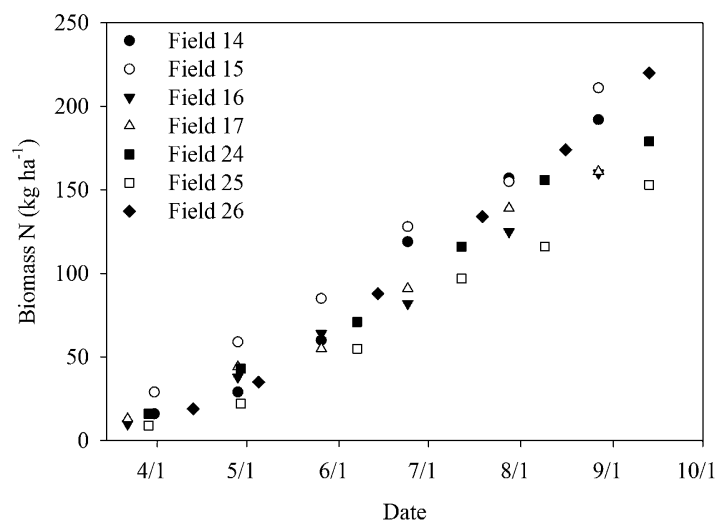

Fig. 2. Aboveground crop biomass nitrogen $(\mathrm{N})$ accumulation (vegetative tissue and marketable fruit) over the growing season in seven strawberry fields; measurements made in 2010 and 2011.

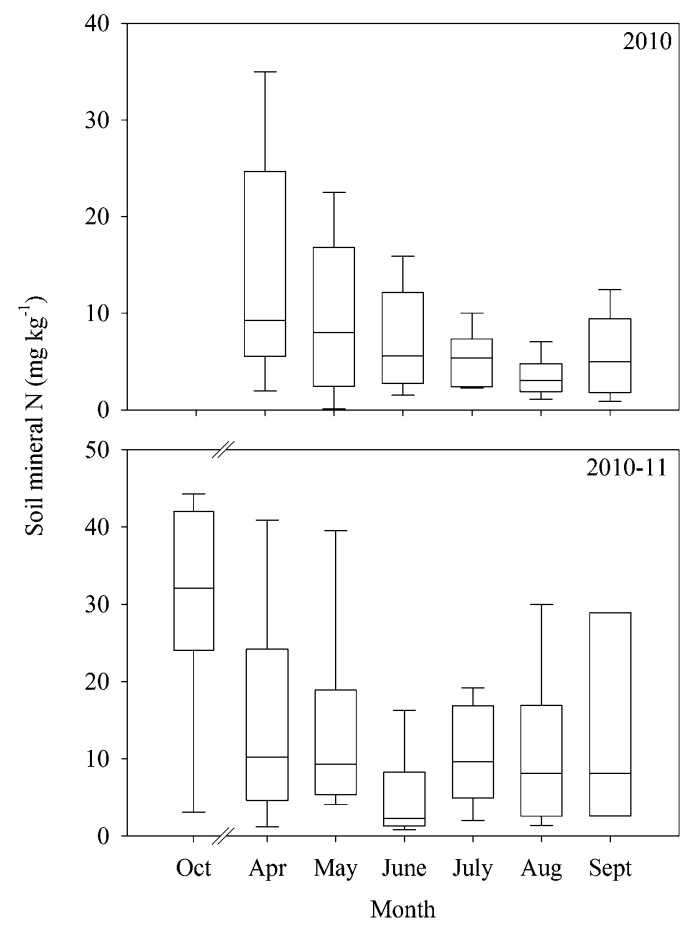

Fig. 3. Seasonal pattern of soil mineral nitrogen (N) (top $30 \mathrm{~cm}$ depth) in 26 strawberry fields. The box encompasses the 25 th and 75 th percentile with the middle bar representing the median value; external bars indicate the 10th and 90th percentile.

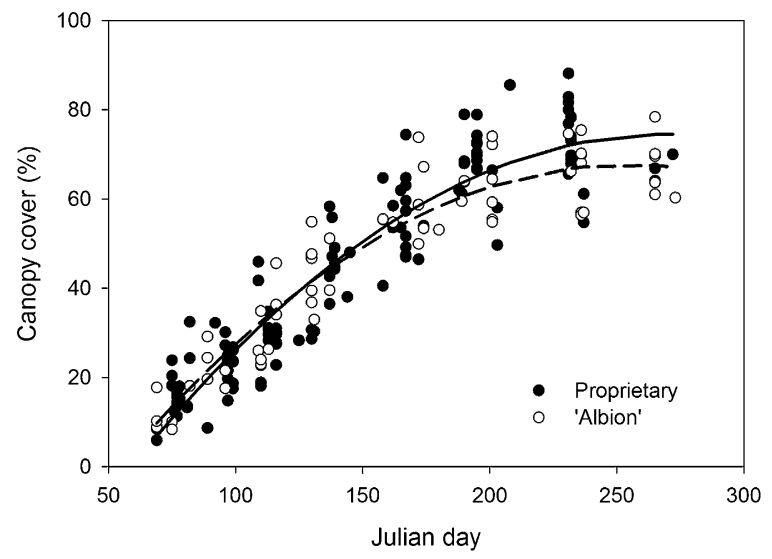

Fig. 4. Plant canopy cover (\% of the ground surface) over the production season in 25 strawberry fields; measurements made in 2010 and 2011 . The solid line represents the model for the proprietary cultivar $\left(\mathrm{y}=0.86 \mathrm{x}-0.0015 \mathrm{x}^{2}-44, r^{2}=0.88\right)$ and the dashed line the model for 'Albion' $\left(\mathrm{y}=0.93 \mathrm{x}-0.0019 \mathrm{x}^{2}-\right.$ $\left.47, r^{2}=0.89\right)$, where $\mathrm{x}=$ Julian day.
November. Grower CRF application rates $\left(121,121\right.$, and $86 \mathrm{~kg} \cdot \mathrm{ha}^{-1} \mathrm{~N}$ in fields 24,25 , and 26 , respectively) were compared with a half rate in all fields and to no CRF in field 26. Each field trial used a randomized complete block experimental design with four blocks. Individual plots representing a CRF rate were $45 \mathrm{~m}$ long and three beds wide (fields 24 and 25 ) or $18 \mathrm{~m}$ long and one bed wide (field 26); bed width was either $1.3 \mathrm{~m}$ (fields 25 and 26) or $1.6 \mathrm{~m}$ (field 24). A tipping bucket rain gauge (Campbell Scientific, Logan, UT) was installed at each site to document rainfall volume. SMN (top $30 \mathrm{~cm}$ depth) at transplant establishment was 19,22 , and 30 $\mathrm{mg} \cdot \mathrm{kg}^{-1}$ in fields 24,25 , and 26 , respectively.

Biomass $\mathrm{N}$ accumulation was estimated at the CRF trial sites three times between late March and early June. At each sampling date, the aboveground biomass of four whole plants per plot was removed and biomass $\mathrm{N}$ was determined as previously described. SMN was determined as previously described in each plot on each plant sampling date. Plots were harvested approximately twice weekly by commercial harvest crews, and marketable fruit yields were recorded from April through September.

The $\mathrm{N}$ release characteristic of the $\mathrm{CRF}$ used in these trials was evaluated using a buried bag technique. Spun-bond polyester bags containing $4 \mathrm{~g}$ of CRF were buried $\approx 10$ $\mathrm{cm}$ deep in the soil beds on 4 Nov. (field 24) or 23 Nov. 2010 (field 25). Burial was done after transplanting to avoid any damage or disruption of the bags during transplanting. Soil temperature at the burial depth was recorded by thermistors (Onset Corp., Pocasset, MA). On approximately monthly intervals beginning in Jan. 2011, three replicate bags of CRF were recovered from each field; the $\mathrm{CRF}$ granules were rinsed to remove adhering soil, oven-dried, weighed, ground, and analyzed for $\mathrm{N}$ concentration by the combustion technique used for plant material. $\mathrm{N}$ released from the CRF by each sampling date was expressed as a percentage of the initial $\mathrm{N}$ content.

Statistical analysis. Canopy cover regressions were calculated using SigmaPlot (Systat Software, Inc., San Jose, CA). All other statistical analyses were conducted using the SAS statistical package (SAS Institute, Cary, NC). The effect of CRF rate on biomass N, SMN, and marketable fruit yield was evaluated using PROC GLM.

\section{Results}

Seasonal N application varied widely among fields, ranging from 141 to 485 $\mathrm{kg} \cdot \mathrm{ha}^{-1}$ (Table 1). All but one field received preplant CRF with $\mathrm{N}$ application rates varying from 50 to $134 \mathrm{~kg} \cdot \mathrm{ha}^{-1}$. The manufacturers' nutrient release ratings for most of the CRF formulations used were between 7 and 10 months. Seasonal $\mathrm{N}$ fertigation rates varied from 40 to $351 \mathrm{~kg} \cdot \mathrm{ha}^{-1}$. Median total $\mathrm{N}$ application and marketable fruit yield were $260 \mathrm{~kg} \cdot \mathrm{ha}^{-1}$ and $77 \mathrm{Mg} \cdot \mathrm{ha}^{-1}$, respectively. 
Aboveground biomass $\mathrm{N}$ accumulation averaged less than $25 \mathrm{~kg} \cdot \mathrm{ha}^{-1}$ through March and then increased linearly over the rest of through mid-September, mean aboveground biomass $\mathrm{N}$ increased by $1.13 \mathrm{~kg} \cdot \mathrm{ha}^{-1} \cdot \mathrm{d}^{-1}$. Based on the linear model (biomass $\mathrm{N}=$ $1.13 \mathrm{x}-99$, where $\mathrm{x}$ is Julian day; $r^{2}=0.90$ ), mean aboveground biomass $\mathrm{N}$ averaged $193 \mathrm{~kg} \cdot \mathrm{ha}^{-1}$ by $15 \mathrm{Sept}$. Cull fruit were not measured in this study, but at an estimated $15 \%$ of total fruit production, would represent an additional $15 \mathrm{~kg} \cdot \mathrm{ha}^{-1} \mathrm{~N}$. Including the production season (Fig. 2). From April

cull fruit, $\mathrm{N}$ uptake was nearly evenly divided between vegetative tissue and fruit. Root $\mathrm{N}$ content was not measured, but based on prior research (Muramoto and Gaskell, 2012; Tagliavini et al., 2005), roots would represent less than $10 \%$ of total biomass N. Thus, total crop $\mathrm{N}$ uptake in the monitored fields was estimated to average $\approx 225 \mathrm{~kg} \cdot \mathrm{ha}^{-1} \mathrm{~N}$ by 15 Sept.

Monitoring in the 2010-11 season showed that SMN at transplanting was generally high (Fig. 3); all fields except the one with the lowest SMN had produced vegetable

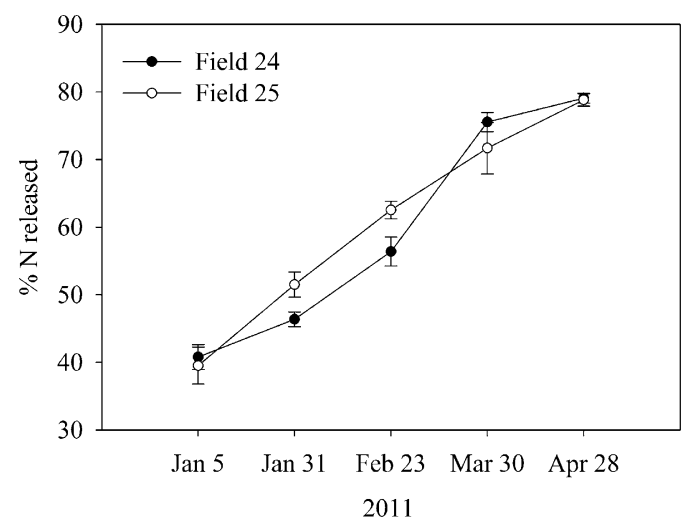

Fig. 5. Pattern of nitrogen release from the controlled-release fertilizer (CRF, 18N-3.5P-10.8K) used in the CRF rate trials; bars represent SE of measurement.

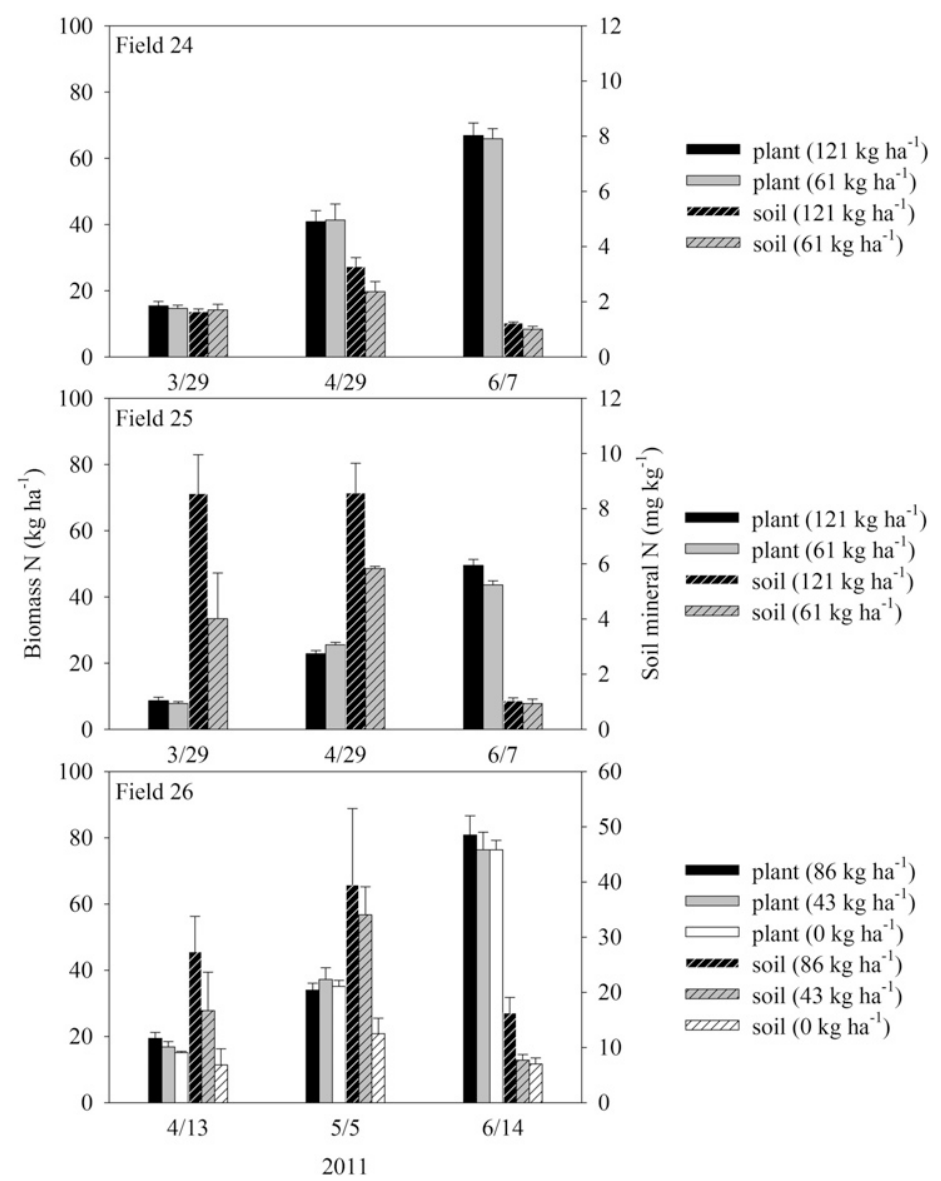

Fig. 6. Effect of preplant controlled-release fertilizer rate on aboveground biomass nitrogen $(\mathrm{N})$ accumulation and soil mineral N; bars indicate SE of measurement. crops the preceding spring. $\mathrm{NO}_{3}-\mathrm{N}$ represented greater than $90 \%$ of SMN across fields and sampling dates. Median SMN decreased from 32 to $10 \mathrm{mg} \cdot \mathrm{kg}^{-1}$ between transplanting and April, despite $\mathrm{N}$ release from the preplant CRF. Because biomass $\mathrm{N}$ accumulation during this period was low, the decline in SMN was attributed primarily to $\mathrm{NO}_{3}-\mathrm{N}$ movement below $30-\mathrm{cm}$ depth as a result of the combined effects of irrigation and winter rain. Median SMN was maintained below $10 \mathrm{mg} \cdot \mathrm{kg}^{-1}$ from May onward in both production seasons, although a minority of growers maintained much higher SMN throughout the summer by heavy $\mathrm{N}$ fertigation.

The pattern of canopy development was similar to that of biomass $\mathrm{N}$ accumulation with canopy cover increasing rapidly from late March through August (Fig. 4). Mean canopy cover by 1 Sept. was $\approx 70 \%$, although plant vigor varied widely among fields. There was a similar pattern of canopy development between cultivars. There was little variability in $\mathrm{ET}_{\mathrm{o}}$ among fields with $\mathrm{ET}_{\mathrm{o}}$ during the main irrigation period (May through September) averaging $61.9 \mathrm{~cm}$. Irrigation applied during that period ranged among fields from 20 to 83 $\mathrm{cm}$; precipitation during that period was less than $7 \mathrm{~cm}$ in both years. Based on the comparison of estimated seasonal $\mathrm{ET}_{\mathrm{c}}$ to irrigation applied, four fields were underirrigated by more than $10 \%$ of seasonal $\mathrm{ET}_{\mathrm{c}}$, whereas in seven fields, seasonal irrigation was within $10 \%$ of $\mathrm{ET}_{\mathrm{c}}$. Irrigation exceeded $\mathrm{ET}_{\mathrm{c}}$ by $10 \%$ to $30 \%$ in six fields and by greater than $30 \%$ in eight fields. Median seasonal irrigation was $113 \%$ of $\mathrm{ET}_{\mathrm{c}}$.

The pattern of $\mathrm{N}$ release from the $18 \mathrm{~N}-$ 3.5P-10.8K CRF was similar in fields 24 and 25 (Fig. 5). Nearly $80 \%$ of the initial N content had been released by the end of April $(\approx 6$ months after burial in the field). This result likely understated the $\mathrm{N}$ release in commercial fields, in which CRF application is done preplant compared with post-planting as was done in this study. Mean soil temperature at CRF burial depth over the evaluation period was $13{ }^{\circ} \mathrm{C}$ in both fields.

CRF rate did not significantly affect aboveground biomass $\mathrm{N}$ in any field through the June sampling date, although CRF rate effects on June biomass $\mathrm{N}$ approached statistical significance in field $25(P=0.055$; Fig. 6). CRF rate did not affect SMN at any sampling date in field 24, but significant differences were observed at all dates in field 26. SMN was influenced by CRF rate at the first two sampling dates in field 25 .

Seasonal marketable fruit yield was unaffected by CRF rate in fields 24 and 26 (Fig. 7). Reducing the CRF rate in field 25 from 121 to $61 \mathrm{~kg} \cdot \mathrm{ha}^{-1}$ resulted in an $8 \%$ reduction in seasonal fruit yield; cumulative marketable fruit yield between the $\mathrm{N}$ rates was significantly different from July through September. The cause of the yield response to the higher CRF rate in field 25 was not clear. Soil phosphorus (P) or $\mathrm{K}$ availability was unlikely to have been a factor given the high $P$ and $K$ status of the field (114 and 416 $\mathrm{mg} \cdot \mathrm{kg}^{-1}$ bicarbonate $\mathrm{P}$ and exchangeable $\mathrm{K}$, 


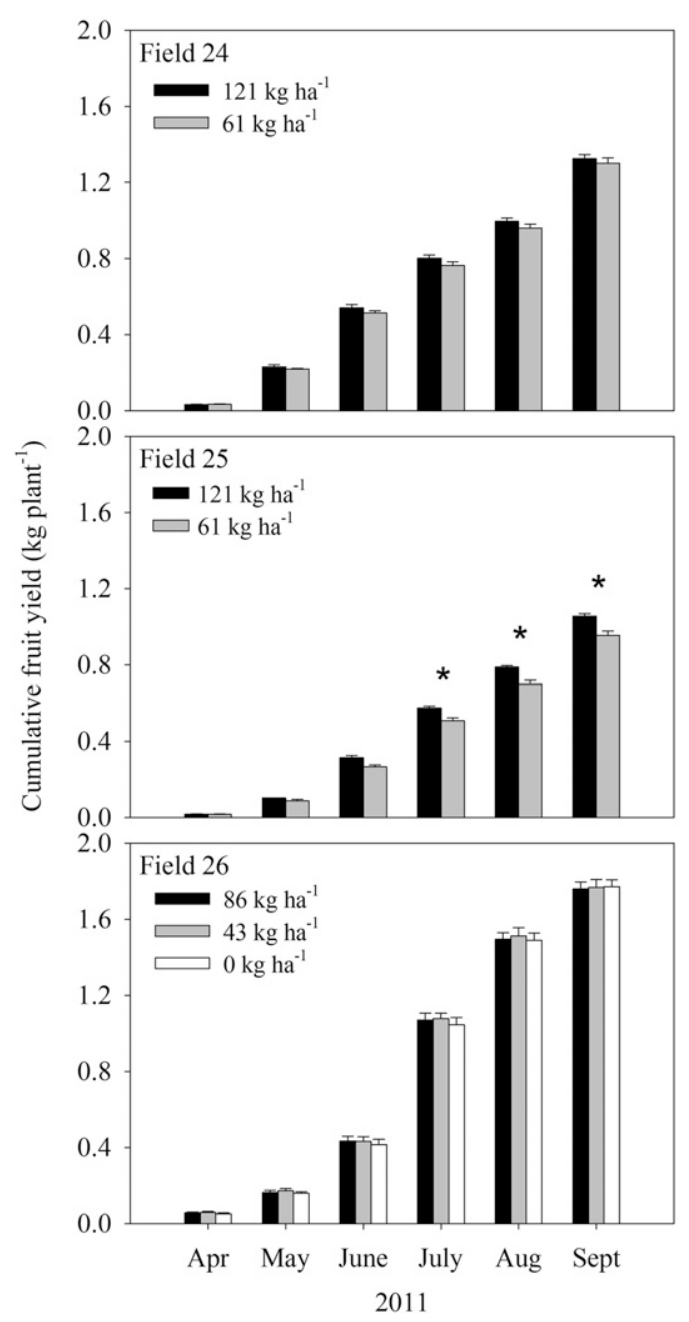

Fig. 7. Effect of preplant controlled-release fertilizer (CRF, $18 \mathrm{~N}-3.5 \mathrm{P}-10.8 \mathrm{~K})$ on cumulative marketable fruit yield; * indicates that CRF rate significantly affected cumulative fruit yield $(P<0.05)$ at the end of the month specified.

respectively). Although CRF rate influenced SMN in March and April, no differences in biomass $\mathrm{N}$ were observed, and SMN was lower on those dates in field 24 , in which both CRF rates produced much higher fruit yield. Field 25 did have the highest seasonal precipitation $(56 \mathrm{~cm}$ by 1 Apr. compared with 36 and $34 \mathrm{~cm}$ at fields 24 and 26, respectively), received the greatest spring irrigation volume (16 $\mathrm{cm}$ in March to April compared with 11 and $6 \mathrm{~cm}$ in fields 24 and 26, respectively), and received minimal $\mathrm{N}$ fertigation in May (13 kg.ha ${ }^{-1}$, below the crop $\mathrm{N}$ uptake rate). Although an $\mathrm{N}$ limitation appeared to affect crop productivity at some point in the spring, it was unclear whether that limitation could have been prevented more efficiently through modified spring irrigation or $\mathrm{N}$ fertigation management rather than reliance on a higher preplant CRF rate.

\section{Discussion}

Strawberry biomass $\mathrm{N}$ accumulation showed a consistent pattern across fields with limited $\mathrm{N}$ accumulation from fall transplanting through March followed by a consistent rate of crop $\mathrm{N}$ uptake through the rest of the production season. The estimated mean seasonal $\mathrm{N}$ uptake of $225 \mathrm{~kg} \cdot \mathrm{ha}^{-1}$ was higher than in previous research (Albregts and Howard, 1980; Latet et al., 2002; Strik et al., 2004; Tagliavini et al., 2004, 2005). Reported strawberry $\mathrm{N}$ uptake has ranged widely from $59 \mathrm{~kg} \cdot \mathrm{ha}^{-1}$ (Albregts and Howard, 1980) to $200 \mathrm{~kg} \cdot \mathrm{ha}^{-1}$ (Latet et al., 2002) with differences driven largely by the level of crop productivity. Nitrogen content of fruit averaged $1.2 \mathrm{Mg} \cdot \mathrm{kg}^{-1}$ fresh weight in these seven fields, similar to that found by Tagliavini et al. (2004) but substantially higher than reported by Black et al. (2005).

Current $\mathrm{N}$ fertilization practices did not efficiently match the crop $\mathrm{N}$ uptake pattern observed. In this region, most strawberry fields are planted after vegetable crops. Those fields typically have significant residual SMN, as shown in this study and in a larger field survey (Bottoms et al., 2012). Therefore, justification for preplant CRF in this production system appeared to be to ensure $\mathrm{N}$ availability throughout the winter, when $\mathrm{NO}_{3}-\mathrm{N}$ leaching by rainfall is possible. However, the replicated trials showed that preplant
CRF rates had a minimal effect on strawberry $\mathrm{N}$ accumulation through the June sampling, by which time the vast majority of CRF $\mathrm{N}$ had been released.

The results of the CRF rate trials were consistent with prior research. Although the value of preplant $\mathrm{N}$ has been shown in some studies (Albregts and Chandler, 1993; Miner et al., 1997; Locascio et al., 1977), preplant N application of no more than $67 \mathrm{~kg} \cdot \mathrm{ha}^{-1} \mathrm{~N}$ was adequate to maximize crop productivity. Other research has shown no benefit to preplant $\mathrm{N}$ fertilization when drip fertigation was effectively used (Albregts et al., 1991b; Santos, 2010).

A partial $\mathrm{N}$ balance suggested that the potential for winter $\mathrm{NO}_{3}-\mathrm{N}$ leaching below $30-\mathrm{cm}$ depth was substantial. The median reduction in SMN between fall planting and the April sampling in the 2010-11 fields averaged $22 \mathrm{mg} \cdot \mathrm{kg}^{-1}$; assuming a typical soil bulk density of $1.4 \mathrm{~g} \cdot \mathrm{cm}^{3}$, that represented $\approx 80 \mathrm{~kg} \cdot \mathrm{ha}^{-1} \mathrm{~N}$. Additionally, at least 70 $\mathrm{kg} \cdot \mathrm{ha}^{-1} \mathrm{~N}$ would have been released from preplant CRF between application in October and the April sampling based on the median CRF application of $101 \mathrm{~kg} \cdot \mathrm{ha}^{-1}$ (Table 1) and an expected $\mathrm{N}$ release of at least $70 \%$ (Fig. 5). However, biomass $\mathrm{N}$ accumulation only averaged $\approx 40 \mathrm{~kg} \cdot \mathrm{ha}^{-1}$ by the end of April (Fig. 2).

By comparison, monitoring showed that irrigation and $\mathrm{N}$ fertigation could be managed during the main irrigation season (May through September) to minimize $\mathrm{NO}_{3}-\mathrm{N}$ leaching potential. In the nine fields with marketable fruit yield of at least $80 \mathrm{Mg} \cdot \mathrm{ha}^{-1}$, estimated seasonal irrigation exceeded $\mathrm{ET}_{\mathrm{c}}$ by an average of only $7 \%$, or $2.5 \mathrm{~cm}$. The mean SMN for those fields over that period was only $7 \mathrm{mg} \cdot \mathrm{kg}^{-1}$. There were a number of fields in which more irrigation was applied, or higher SMN was maintained, but justification for those practices was unclear; across all fields, seasonal fruit yield was not correlated with irrigation volume applied, preplant CRF $\mathrm{N}$ rate, seasonal $\mathrm{N}$ application, or mean SMN maintained during the fruiting season.

This study suggested several ways in which $\mathrm{N}$ management could be improved in this production system. The replicated CRF rate trials indicated that routine use of high CRF rates was not an efficient practice. Reducing CRF rates, particularly in heavier textured soils that are less easily leached, could substantially improve $\mathrm{N}$ use efficiency. Using CRF formulations that have slower $\mathrm{N}$ release characteristics would reduce winter $\mathrm{N}$ release, when crop N uptake is low. However, the long period between CRF application and rapid growth in the spring (at least 5 months), and the relatively mild winter soil temperature, make it inevitable that CRF $\mathrm{N}$ release and crop $\mathrm{N}$ uptake will not be ideally matched. Reducing reliance on preplant CRF may require increased monitoring of SMN during the winter and early spring and an earlier start on $\mathrm{N}$ fertigation in production seasons with high winter rainfall.

Efficient drip irrigation management was demonstrated in many fields; in only one of 
the nine highest yielding fields was seasonal irrigation more than $120 \%$ of $\mathrm{ET}_{\mathrm{c}}$. The consistency of crop $\mathrm{N}$ uptake over the spring and summer $\left(\approx 1.1 \mathrm{~kg} \cdot \mathrm{ha}^{-1} \cdot \mathrm{d}^{-1}\right)$ provided a guideline for $\mathrm{N}$ fertigation. Adjusting for higher fruit yield potential under California conditions, that recommendation supported prior research that found $\mathrm{N}$ fertigation averaging 0.5 to $0.9 \mathrm{~kg} \cdot \mathrm{ha}^{-1} \cdot \mathrm{d}^{-1}$ to be adequate for peak production (Hochmuth et al., 1996; Miner et al., 1997; Santos and Chandler, 2009).

\section{Literature Cited}

Albregts, E.E. and C.K. Chandler. 1993. Slow release fertilizer rates for strawberry fruit production. Proc. Fla. State Hort. Soc. 106:187-189.

Albregts, E.E. and C.M. Howard. 1980. Accumulation of nutrients by strawberry plants and fruit grown in annual hill culture. J. Amer. Soc. Hort. Sci. 105:386-388.

Albregts, E.E., C.M. Howard, and C.K. Chandler. 1991a. Effect of high $\mathrm{N}$ rates on fruiting strawberry. Soil Crop Sci. Soc. Fl. 50:134-136.

Albregts, E.E., G.A. Clark, C.D. Stanley, F.S Zazueta, and A.G. Smajstrla. 1991b. Preplant fertilization of fruiting microirrigated strawberry. HortScience 26:1176-1177.

Black, B.L., S.C. Hokanson, and K.S. Lewers. 2005. Fruit nitrogen content of sixteen strawberry genotypes grown in an advanced matted row production system. HortScience 40:1190-1193.

Bottoms, T.G., R.F. Smith, M.D. Cahn, and T.K. Hartz. 2012. Nitrogen requirements and $\mathrm{N}$ status determination of lettuce. HortScience 47:1768-1774.

Doane, T.A. and W.R. Horwath. 2003. Spectrophotometric determination of nitrate with a single reagent. Anal. Lett. 36:2713-2722.

Forster, J.C. 1995. Soil nitrogen, p. 79-87. In: Alef, K. and P. Nannipieri (eds.). Methods in applied soil microbiology and biochemistry. Academic Press, San Diego, CA.

Grattan, S.R., W. Bowers, A. Dong, R.L. Snyder, J.J. Carroll, and W. George. 1998. New crop coefficients estimate water use of vegetables, row crops. Calif. Agr. 52:16-21.

Hanson, B. and W. Bendixen. 2004. Drip irrigation evaluated in Santa Maria Valley strawberries. Calif. Agr. 58:48-53.

Hart, Q.J., M. Brugnach, B. Temesgen, C. Rueda, S.L. Ustin, and K. Frame. 2009. Daily reference evapotranspiration for California using satellite imagery and weather station measurement interpolation. Civ. Eng. Environ. Syst. 26:1933.

Hochmuth, G.J., E.E. Albregts, C.C. Chandler, J. Cornell, and J. Harrison. 1996. Nitrogen fertigation requirements of drip-irrigated strawberries. J. Amer. Soc. Hort. Sci. 121:660-665.

Kirschbaum, D.S., A.M. Borquez, S.L. Quipildor, M. Correa, H. Magen, and P. Imas. 2006. Nitrogen requirements of drip irrigated strawberries grown in subtropical environments. Acta Hort. 708:93-96.

Latet, G., P. Meesters, and J. Bries. 2002. The influence of different nitrogen $(\mathrm{N})$ sources on the yield and leaching in open field strawberry production. Acta Hort. 567:455-458.

Locascio, S.J. and F.G. Martin. 1985. Nitrogen source and application timing for trickle irrigated strawberries. J. Amer. Soc. Hort. Sci. 110:820-823.

Locascio, S.J., J.M. Myers, and F.G. Martin. 1977. Frequency and rate of fertilization with trickle irrigation in strawberry. J. Amer. Soc. Hort. Sci. 102:456-458

Maas, E.V. 1984. Salt tolerance of plants, p. 57-75. In: Christie, B.R. (ed.). Handbook of plant science in agriculture. CRC Press Inc., Boca Raton, FL.

Miner, G.S., E.B. Poling, D.E. Carroll, L.A. Nelson, and C.R. Campbell. 1997. Influence of fall nitrogen and spring nitrogen-potassium applications on yield and fruit quality of 'Chandler' strawberry. J. Amer. Soc. Hort. Sci. 122:290-295.

Muramoto, J. and M. Gaskell. 2012. Nitrogen management for organic strawberries, p. 4353. In: Koike, S.T., C.T. Bull, M.P. Bolda, and O. Daugovish (eds.). Organic strawberry production manual. Univ. of Calif. Publication 3531.

Olsen, S.R. and L.E. Sommers. 1982. Phosphorus, p. 403-430. In: Page, A.L., R.H. Miller, and D.R. Keeney (eds.). Methods of soil analysis: Part 2. Chemical and microbiological properties. Monograph Number 9. American Society of Agronomy, Madison, WI.

Prokopy, W.R. 1995. Phosphorus in 0.5 M sodium bicarbonate soil extracts. QuikChem Method 12-115-01-1-B. Lachat Instruments, Milwaukee, WI.

Pruitt, W.D., E. Fereres, and R.L. Snyder. 1987. Reference evapotranspiration $\left(\mathrm{ET}_{\mathrm{o}}\right)$ for California. Univ. of Calif. Coop. Ext. Bul. 1922.
Santos, B.M. 2010. Effects of preplant nitrogen and sulfur fertilizer sources on strawberry. HortTechnology 20:193-196.

Santos, B.M. and C.K. Chandler. 2009. Influence of nitrogen fertilization rates on the performance of strawberry cultivars. Intl. J. Fruit Sci. 9:126135.

Serrano, L., X. Carbonell, R. Save, O. Marfa, and J. Penuelas. 1992. Effects of irrigation regimes on the yield and water use of strawberry. Irrig. Sci. 13:45-48.

Shaw, D.V. and K.D. Larson. 2008. Performance of early-generation and modern strawberry cultivars from the University of California breeding programme in growing systems simulating traditional and modern horticulture. J. Hort. Sci. Biotechnol. 83:648-652.

Sheldrick, B.H. and C. Wang. 1993. Particle size distribution, p. 499-511. In: Carter, M.R. (ed.). Soil sampling and methods of analysis. Canadian Society of Soil Science, Ottawa, Ontario, Canada.

Strand, L.L. 1994. Integrated pest management for strawberries. Univ. of Calif. Publication 3351.

Strik, B., T. Righetti, and G. Buller. 2004. Influence of rate, timing, and method of nitrogen fertilizer application on uptake and use of fertilizer nitrogen, growth, and yield of Junebearing strawberry. J. Amer. Soc. Hort. Sci. 129:165-174.

Tagliavini, M., E. Baldi, P. Lucchi, M. Antonelli, G. Sorrenti, G. Baruzzi, and W. Faedi. 2005. Dynamics of nutrient uptake by strawberry plants (Fragaria $\times$ Ananassa Dutch.) grown in soil and soilless culture. Eur. J. Agron. 23:15-25.

Tagliavini, M., E. Baldi, R. Nestby, C. RaynalLacroix, P. Lieten, T. Salo, D. Pivot, P.L. Lucchi, G. Baruzzi, and W. Faedi. 2004. Uptake and partitioning of major nutrients by strawberry plants. Acta Hort. 640:197200.

Thomas, G.W. 1982. Exchangeable cations, p. 159-165. In: Page, A.L., R.H. Miller, and D.R. Keeney (eds.). Methods of soil analysis: Part 2. Chemical and microbiological properties. Monograph Number 9. American Society of Agronomy, Madison, WI.

USDA, Economic Research Service. 2012. U.S. strawberry industry. <http://usda.mannlib. cornell.edu/MannUsda/viewDocumentInfo. do? documentID=1381>. 